\title{
Maize Yield Response under Various Phosphorus Sources and their Ratios
}

\section{Waqar Ali1 ${ }^{*}$, Mukhtiar Ali ${ }^{1}$, Abid Kamal ${ }^{1}$, Muhammad Uzair ${ }^{2}$, Nasr Ullah ${ }^{3}$, Muhammad Daud Khan ${ }^{4}$ and Mussaddiq Khan Khalil ${ }^{1}$}

${ }^{1}$ Department of Soil and Environmental Sciences, The University of Agriculture, Peshawar, Pakistan

${ }^{2}$ Department of Food Science and Technology, The University of Agriculture, Peshawar, Pakistan

3Department of Agronomy, The University of Agriculture, Peshawar, Pakistan

${ }^{4}$ Institute of Biotechnology and Genetic Engineering, The University of Agriculture, Peshawar, Pakistan

*Corresponding author: Waqar Ali, Department of Soil and Environmental Sciences, The University of Agriculture, Peshawar, Pakistan, E-mail: waqarali@aup.edu.pk

Received Date: April 3, 2019; Accepted Date: April 10, 2019; Published Date: April 30, 2019

Copyright: (c) 2019 Ali W, et al. This is an open-access article distributed under the terms of the Creative Commons Attribution License, which permits unrestricted use, distribution, and reproduction in any medium, provided the original author and source are credited.

Citation: Ali W, Ali M, Kamal A, Uzair M, Ullah N, et al. (2019) Maize Yield Response under Various Phosphorus Sources and their Ratios Eur Exp Biol Vol.9 No.1:5.

\section{Abstract}

Improper use of fertilizers and its ratio is one of the main reasons for low productivity; therefore balance fertilization is required to maintain crop production and improved soil fertility. Therefore the experiment was carried out at Cereal Crop Research Institute (CCRI) Pirsabak, Distract Nowshera $\mathrm{KP}$, Pakistan during Kharif 2016. To study the effect of different phosphorus $(P)$ sources and their ratios on maize yield and yield components, an experiment was carried out in a Randomized Complete Block Design (RCBD) with three replication. The treatments consisted of sole application of Farmyard Manure (FYM), Poultry Manure (PM) and Diammonium Phosphate (DAP), 75\% FYM+25\% DAP, 50\% $\mathrm{FYM}+50 \% \mathrm{DAP}, 75 \% \mathrm{PM}+25 \% \mathrm{DAP}, 50 \% \mathrm{PM}+50 \% \mathrm{DAP}$ and a control treatment with no $\mathrm{P}$ fertilizer. Phosphorus was applied at the rate of $100 \mathrm{~kg} \mathrm{ha}^{-1}$ from different sources in different ratios. The results indicated a significant effect of different phosphorus sources on days to tasselling, days to silking, days to maturity, plant height, grains ear ${ }^{-1}$, grain yield, biological yield, and harvest index, whereas the emergence $\mathrm{m}^{-2}$ was found non-significant with different $P$ sources. The combined use of organic and inorganic $P$ sources delayed tasselling, silking and maturity. Plant height, grains ear ${ }^{-1}$, biological yield, grain yield, and harvest index was also higher with the addition of $P$ from both sources as compared with the sole application of organic or inorganic fertilizer. The combined application of organic manures 50:50 (FYM or PM) and inorganic fertilizer (DAP) performed better as compared to the rest of the ratios and produced higher yield and yield components.

Keywords: Farmyard manure (FYM); Poultry manure (PM); DAP; Grain yield; Nowshera; Khyber pakhtunkhwa (KP); Pakistan

\section{Introduction}

Maize (Zea mays L.) is one of the important cereal crop its ranks $3^{\text {rd }}$ in Pakistan after wheat and rice. The average yield of maize in Pakistan is $3983 \mathrm{~kg} \mathrm{ha}^{-1}$ which is much lower in other growing world countries [1]. C4 mode carbon fixation was found in maize due to its high biomass and its rapid growth, therefore, its need balance nutrient application. Phosphorus is one of the most important nutrients for improving yield and crop growth [2]. Due to unavailability of $P$ crop yield is reduced up to $30 \%$ [3] and also lower $\mathrm{P}$ use efficiency. Inorganic phosphorus fertilizers, continuously lead phosphorus to a negative response. It could run out about 60 to 100 years if its current consumption continues and there will be no agriculture without $P$ [4]. In Pakistan like another arid region of the world, about $80 \%$ to $90 \%$ soils are deficient in available $P$ [5]. In Pakistani soil fertility survey reported that $\mathrm{P}$ after $\mathrm{N}$ is the most deficient nutrient [6].

$P$ application and organic manure are very essential for $P$ availability and as well as yield profitability [7]. Under the semiarid condition, the major limiting factor of crop production is the unavailability of $P$ and lack of organic matter. Phosphorus is an important essential macronutrient often limiting plant growth due to fixation in soils and its low solubility. Bound $P$ by microbial inoculants is an important factor for increasing productivity and improving soil fertility [8]. Due to low fertilizers use efficiency the crop yields in Pakistan are either stagnant or not increasing [9]. Unavailability and inadequate supply of fertilizers at the time of requirement adulteration and high cost [10]. A large amount of energy and high cost are required for the synthesis of chemical fertilizers. Moreover, the continuous use of chemical fertilizers creates an environmental problem [4]. Be that as it may, natural cultivating, with or without concoction composts is by all accounts a conceivable answer for the predominant circumstances [11]. The joining of natural supplement sources with engineered ones supply basic supplements as well as has some positive cooperation with synthetic manures to expand their proficiency in this way 
decreasing ecological risks [12]. Non-customary squanders like poultry excrement and press mud from the sugar industry are of concern and should be overseen in ecological point of view.

It is apparent from various investigations, reusing and expansion of mechanical and agrarian squanders to soil may improve the productivity of connected and local supplements required by harvests. Joining of channel cake as the natural waste with Single Super Phosphate (SSP) in 2:1 proportion brought about expanded plant stature, number of tillers per plant, straw and grain yield of wheat just as $P$ take-up by grain over control [13]. Amujoyegbe BJ et al. Found most astounding grain yield and biomass of maize and sorghum with the consolidated use of inorganic compost+poultry excrement pursued by inorganic manure [14]. In another examination, utilization of poultry excrement either alone or coordinated with synthetic changes of $\mathrm{P}$ for maize, performed superior to anything all alterations tried in research facility trails [15]. Hussain $A$ et al. Prescribed that natural issue alone with manufactured manures could be useful for upgrading stale wheat grain yield, Therefore, prudent and efficient utilization of the current land, supplement composts application, budgetary assets and reusing of natural squanders under field conditions is unavoidable [16].

Keeping in view the importance of phosphorus and the problem of the high price of chemical fertilizer, the present study was conducted to evaluate the effect of different phosphorus sources and their ratios on yield and yield components of maize under the climatic condition of Nowshera.

\section{Materials and Methods}

The experiment entitles "Response of Maize yield under various levels of nitrogen and zinc fertilizers" was carried out at Cereal Crop Research Institute (CCRI) Pirsabak, Distract Nowshera KP, Pakistan during Kharif 2016. The experiment factor along with their levels is as under (Table 1).

Table 1: Treatment combination.

\begin{tabular}{|l|l|l|l|}
\hline Treatment & Organic manure & DAP & Desired $\mathbf{P}\left(\mathbf{k g ~ h a}^{-1}\right)$ \\
\hline $\mathrm{T} 1$ & 0 & 0 & 0 \\
\hline $\mathrm{T} 2$ & $100 \% \mathrm{FYM}$ & 0 & 100 \\
\hline $\mathrm{T} 3$ & $75 \% \mathrm{FYM}$ & $25 \%$ & 100 \\
\hline $\mathrm{T} 4$ & $50 \% \mathrm{FYM}$ & $50 \%$ & 100 \\
\hline T5 & $100 \% \mathrm{PM}$ & 0 & 100 \\
\hline T6 & $75 \% \mathrm{PM}$ & $25 \%$ & 100 \\
\hline T7 & $50 \% \mathrm{PM}$ & $50 \%$ & 100 \\
\hline T8 & 0 & $100 \%$ & 100 \\
\hline
\end{tabular}

The following parameters were recorded during the experiment:

- Emergence $\mathrm{m}^{-2}$

- Days to $75 \%$ tasseling

- Days to $75 \%$ silking
- Plant height $(\mathrm{cm})$

- Days to maturity

- Number of grains $\left(\right.$ ear $\left.^{-1}\right)$

- Biological yield $\left(\mathrm{kg} \mathrm{ha}^{-1}\right)$

- Grain yield (kg ha-1)

- Harvest index (\%)

\section{Emergence $\mathrm{m}^{-2}$}

Data on emergence $\mathrm{m}^{-2}$ were taken by counting the number of seedlings emerged in a one-meter long row at three random places in each plot after $80 \%$ emergence and were converted to $\mathrm{m}^{-2}$.

\section{Days to $75 \%$ tasseling}

Days to tasseling were recorded by counting the number of days from sowing to date when $75 \%$ of plants produced tassels in each subplot.

\section{Days to $75 \%$ silking}

Data regarding days to silking were recorded by counting the number of days from sowing to date when $75 \%$ of plants produced silks in each subplot.

\section{Plant height $(\mathrm{cm})$}

Plant height was recorded at physiological maturity stage. Five representative plants from each subplot were selected randomly and were measured from base to the tip of tassel with meter rod and then their average was worked out.

\section{Number of grains ear ${ }^{-1}$}

Data on a number of grains ear ${ }^{-1}$ was recorded by counting the number of grains in five ears randomly selected in from each subplot and were averaged.

\section{Biological yield $\left(\mathrm{kg} \mathrm{ha}^{-1}\right)$}

Four central rows in each subplot were harvested; sun-dried and were weighed for recording biological yield data, then converted into $\mathrm{kg} \mathrm{ha}^{-1}$ by the formula.

$$
\begin{aligned}
& \text { Biological yield }\left(\mathrm{kg} \mathrm{ha}^{-1}\right)= \\
& \frac{\text { Biological yield in } 4 \text { rows }}{\mathrm{R}-\mathrm{R}(\mathrm{m}) \times \text { Row length }(\mathrm{m}) \times \text { No of rows }} \times 10000 \mathrm{~m}^{2}
\end{aligned}
$$

\section{Grain yield $\left(\mathrm{kg} \mathrm{ha}^{-1}\right)$}

Ears from four rows harvested for biological yield were shelled and grains were weighed to determine the grain yield and then converted into $\mathrm{kg} \mathrm{ha}^{-1}$ by using the formula.

$$
\begin{aligned}
& \text { Grain yield }\left(\mathrm{kg} \mathrm{ha}^{-1}\right)= \\
& \frac{\text { Grain yield in } 4 \text { rows }}{\mathrm{R}-\mathrm{R}(\mathrm{m}) \times \text { Row length }(\mathrm{m}) \times \text { No of rows }} \times 10000 \mathrm{~m}^{2}
\end{aligned}
$$




\section{Harvest index (\%)}

Harvest index (\%) was calculated by using the formula.

Harvest index $(\%)=\frac{\text { Economic yield }\left(\mathrm{kg} \mathrm{ha}^{-1}\right)}{\text { Biological yield }\left(\mathrm{kg} \mathrm{ha}^{-1}\right)} \times 100$

\section{Statistical analysis}

The data were analyzed statistically according to the analysis of variance techniques used for randomized complete block design and Least Significant Difference (LSD) test was applied when the means were found significant by the procedure suggested by Jan MT et al. [17].

\section{Result and Discussion}

\section{Emergence $\mathrm{m}^{-2}$}

Data regarding emergence $\mathrm{m}^{-2}$ of maize indicated the nonsignificant effect of different phosphorus (P) sources (Table 2). The control vs. rest comparison was also found non-significant for emergence $m^{-2}$. The insignificant effect of different $P$ sources on emergence $\mathrm{m}^{-2}$ might be due to the fact that at earlier stages of growth the seedlings take nutrients from stored food in seeds, that is why there was no effect of externally supplied nutrients, moreover the emergence $\mathrm{m}^{-2}$ is also dependent on seed rate and uniform seed rate did not differ the emergence $\mathrm{m}^{-2}$. Similar results were reported earlier by Akhtar $M$ et al. who reported that there was no effect of externally supplied nutrients on emergence $\mathrm{m}^{-2}$ of the crop $[18,19]$.

\section{Days to tasseling}

Days to tasseling of maize was significantly affected by different $P$ sources (Table 2). The control vs. rest comparison was also found significant. Mean values of the data showed that more days to tasseling (53 days) were taken by the plots treated with $50 \%$ poultry manure and $50 \%$ DAP, which was statistically similar with days to tasseling (52 days) taken with $100 \%$ poultry manure. Lower days to tasselling (50 days) were recorded with the addition of $75 \%$ poultry manure and $25 \%$ DAP. The planned mean comparison of control vs. fertilized plots revealed that more days to tasseling (51 days) were taken by fertilized plots as compared to unfertilized plots (49 days). The increase in days to tasseling with the application of $\mathrm{P}$ might be due to the reason that $P$ enhances the growth of the crop and thus providing sufficient nutrients increased the life cycle of the plants, moreover, organic source provided nutrients throughout the life cycle and thus enhanced the growth of the crop. These results are in contrast with Khan $F$ et al. [20] who reported a nonsignificant effect of $P$ on days to tasseling of maize.

\section{Days to silking}

Statistical analysis of the data indicated that different $P$ sources significantly affected days to silking of maize (Table 2 ). The planned mean comparison of control vs. rest was also found significant. Mean values of the data revealed that number of days to silking (57 days) were taken with the addition of applied (c) Under License of Creative Commons Attribution 3.0 License
$50 \%$ from poultry manure and $50 \%$ DAP, which was statistically at par with $\mathrm{P}$ from poultry manure. Lower days to silking (55 days) were recorded with the addition of DAP alone or in combination with $50 \%$ from FYM (54 days). The fertilized plots took more days to silking ( 55 days) as compared to control plots (53 days). The reason for delayed silking due to $P$ might be that $P$ enhanced the root development and thus facilitated the nutrients uptake and increased the growth and development. These results are in line with Amanullah et al. [21] who reported delayed silking with the addition of poultry manure and $P$.

Table 2: Emergence $\mathrm{m}^{-2}$, days to tasselling and days to silking of maize as affected by different $P$ sources.

\begin{tabular}{|c|c|c|c|}
\hline P Sources & Emergence $\mathbf{m}^{-2}$ & Days to tasseling & Days to silking \\
\hline $100 \%$ FYM & 6.57 & $51.67 \mathrm{ab}$ & $56.00 \mathrm{ab}$ \\
\hline $75 \%$ FYM & 6.43 & $50.67 \mathrm{~b}$ & $55.67 \mathrm{ab}$ \\
\hline $50 \%$ FYM & 6.77 & $50.33 b$ & $54.33 b$ \\
\hline $100 \% \mathrm{PM}$ & 6.73 & $52.00 \mathrm{a}$ & $56.00 \mathrm{a}$ \\
\hline $75 \%$ PM & 6.73 & $50.00 \mathrm{~b}$ & $53.33 \mathrm{~b}$ \\
\hline $50 \% \mathrm{PM}$ & 6.67 & $53.00 \mathrm{a}$ & $57.33 \mathrm{a}$ \\
\hline $100 \%$ DAP & 6.63 & $51.00 \mathrm{~b}$ & $55.00 \mathrm{~b}$ \\
\hline $\operatorname{LSD}(0.05)$ & NS & 1.6 & 2.27 \\
\hline Control vs rest & NS & ** & * \\
\hline Control & 6.7 & 49.33 & 53.33 \\
\hline Rest & 6.65 & 51.24 & 55.38 \\
\hline \multicolumn{4}{|c|}{$\begin{array}{l}\text { Means followed by different letters are statistically different from each other at } \\
5 \% \text { or } 1 \% \text { level of probability }\end{array}$} \\
\hline \multicolumn{4}{|c|}{ NS $=$ no significant at $5 \%$ level of probability } \\
\hline \multicolumn{4}{|c|}{${ }^{*}, * *=$ significant at $5 \%$ and $1 \%$ level of probability respectively } \\
\hline
\end{tabular}

\section{Plant height $(\mathrm{cm})$}

Plant height of maize was significantly affected by different $P$ sources (Table 3 ). The control vs. rest comparison was also found significant. Data regarding $P$ sources revealed that taller plants $(195.1 \mathrm{~cm})$ were produced when $P$ was applied $50 \%$ from FYM and $50 \%$ from DAP, which was statistically at par with plant height $(196.9 \mathrm{~cm})$ attained with the addition of $75 \% \mathrm{P}$ from poultry manure and $25 \%$ from DAP, plant height was lower $(179.6 \mathrm{~cm})$ with addition of $100 \%$ poultry manure. Moreover taller plants $(188.1 \mathrm{~cm})$ were produced in fertilized plots as compared to unfertilized plots $(170.3 \mathrm{~cm})$. The probable reason for the increase in plant height due to $P$ might be that it improved the root development and nutrient absorption which had a great effect on overall plant growth performance which resulted in taller plants, moreover $P$ availability from organic manures is very slow, therefore application of organic $P$ in combination with inorganic increased the availability of $P$ which enhanced plant growth. Similar results were reported earlier by Liu Z et al. [22,27] who reported that combine application of organic and inorganic $\mathrm{P}$ increased the plant height. 


\section{Days to maturity}

Data regarding days to maturity revealed the profound effect of different $P$ sources (Table 3 ). The control vs. rest comparison was also found significant for days to maturity of maize. Mean values of the data showed that more days to maturity (99) were taken with the addition of P 50\% form FYM and 50\% from DAP, statistically similar days to maturity (98.8) were taken when $P$ was applied in 50:50 ratio of poultry manure and DAP, while early maturity was observed with the addition of organic or inorganic $P$ alone. The reason for delayed maturity due to $P$ might be the better growth and development with the application of $P$ which enhanced the lifecycle of the crop and delayed the maturity. These results are in line with Ali $W$ et al. $[12,28]$ who reported a significant effect of $P$ on days to maturity of maize.

\section{Grains ear-1}

The number of grains ear ${ }^{-1}$ was considerably affected by different $P$ sources (Table 3 ). The control vs. rest comparison was also found significant. The number of grains ear ${ }^{-1}$ was higher (442 and 435) with the addition of organic and inorganic $P$ in 50:50 ratio regardless of manure types, statistically similar number of grains ear ${ }^{-1}$ (432) were recorded when $P$ was applied from poultry manure and DAP in 75:25 ratio, while the number of grains ear ${ }^{-1}$ were lower when $\mathrm{P}$ was applied from organic or inorganic source alone. Similarly, the fertilized plots produced a number of grains ear ${ }^{-1}$ (407) as compared with unfertilized plots (354). The increase in number of grains ear ${ }^{-1}$ might be due to the fact that $P$ is an essential nutrient and involved in many physiological processes which are necessary for better growth and development which resulted in more number of grains, moreover the organic manure applied alone released nutrient slowly and timely availability of nutrients are not ensured which reduced the growth comparatively and resulted in low seed set. These results are similar with the results of Liu Z et al. [22,23].

Table 3: Plant height $(\mathrm{cm})$, days to maturity and grains ear ${ }^{-1}$ of maize as affected by different $P$ sources.

\begin{tabular}{|l|l|l|l|}
\hline P Sources & Plant height (cm) & Days to maturity & Grains ear $^{-1}$ \\
\hline $100 \%$ FYM & $185.42 \mathrm{~b}$ & $94.33 \mathrm{~b}$ & $384.4 \mathrm{~b}$ \\
\hline $75 \%$ FYM & $185.28 \mathrm{~b}$ & $96.67 \mathrm{ab}$ & $372.3 \mathrm{~b}$ \\
\hline $50 \%$ FYM & $195.51 \mathrm{a}$ & $99.00 \mathrm{a}$ & $442.5 \mathrm{a}$ \\
\hline $100 \%$ PM & $179.58 \mathrm{~b}$ & $95.33 \mathrm{~b}$ & $405.3 \mathrm{ab}$ \\
\hline $75 \%$ PM & $196.93 \mathrm{a}$ & $94.67 \mathrm{~b}$ & $432.3 \mathrm{a}$ \\
\hline $50 \%$ PM & $191.63 \mathrm{ab}$ & $98.67 \mathrm{a}$ & $434.0 \mathrm{a}$ \\
\hline $100 \%$ DAP & $182.37 \mathrm{~b}$ & $95.00 \mathrm{~b}$ & $380.1 \mathrm{~b}$ \\
\hline LSD (0.05) & 9.97 & 3.27 & 39.8 \\
\hline Control vs. rest & $* *$ & $* *$ & $4 *$ \\
\hline Control & 170.33 & 92.67 & 353.5 \\
\hline Rest & 188.1 & 96.24 & 407.3 \\
\hline
\end{tabular}

Means followed by different letters are statistically different from each other at $5 \%$ or $1 \%$ level of probability

NS=non-significant at $5 \%$ level of probability

${ }^{*},{ }^{* *}=$ significant at $5 \%$ and $1 \%$ level of probability respectively

\section{Biological yield $\left(\mathrm{kg} \mathrm{ha}^{-1}\right)$}

The biological yield of maize was significantly affected by different $P$ sources (Table 4). The control vs. rest comparison was also found significant. Mean values of the data indicated that biological yield was higher with the addition of combine $P$ form organic and inorganic sources, however, the application of $P$ from organic or inorganic source alone produced lower biological yield. The control plots produced lower biological yield as compared with fertilized plots. The increased in biological yield due to combining application of $P$ form organic and inorganic source might be that organic manures improved soil health and timely supplied nutrients by inorganic fertilizer which resulted in better growth and development and thus increased the biological yield of maize. Similar results were earlier reported by Ali $\mathrm{M}$ et al. [23,24].

\section{Grain yield $\left(\mathrm{kg} \mathrm{ha}^{-1}\right)$}

Grain yield of maize was significantly affected by different $P$ sources (Table 4). The control vs. rest comparison was also found significant. Mean values of the data indicated that grain yield was higher with the addition of combine $P$ form organic and inorganic sources, however, application of $\mathrm{P}$ from organic or inorganic source alone produced lower grain yield. The control plots produced lower grain yield as compared with fertilized plots. The increase in grain yield due to combining application of $P$ form organic and inorganic source might be due to the higher yield components like grains ear ${ }^{-1}$ and higher growth with the addition of $P$ from combining organic and inorganic sources. These results are in agreement of those reported by Ali $\mathrm{W}$ et al. $[12,25]$ who reported higher grain yield with the combined application of $\mathrm{P}$ from organic and inorganic sources.

\section{Harvest index (\%)}

Harvest index of maize was significantly affected by different $P$ sources (Table 4). The control vs. rest comparison was also found significant. Higher harvest index (31.8\% and 31.2\%) was calculated for the combined application of $P$ in 50:50 of FYM or poultry manure and DAP, whereas lower harvest index (26.5) was calculated for FYM applied alone. The fertilized plots had higher harvest index (28.9\%) as compared to unfertilized plots (24.9\%). The harvest index is the ratio of grain yield to biological yield which increased with higher grain ratio, the probable reason for higher harvest index might be that higher grain to Stover ratio due to combining application of organic and inorganic $P$ similar results were reported earlier by Luo $B$ et al. $[26,29]$.

Table 4: Biological, grain yield $\left(\mathrm{kg} \mathrm{ha}^{-1}\right)$ and harvest index (\%) of maize as affected by different $P$ sources.

\begin{tabular}{|c|l|l|l|}
\hline P Sources & $\begin{array}{l}\text { Biological yield (kg } \\
\left.\text { ha }^{-1}\right)\end{array}$ & $\begin{array}{l}\text { Grain yield (kg } \\
\text { ha-1) }\end{array}$ & $\begin{array}{l}\text { Harvest index } \\
(\%)\end{array}$ \\
\hline
\end{tabular}




\begin{tabular}{|l|l|l|l|}
\hline $100 \%$ FYM & $10144 \mathrm{~b}$ & $2661 \mathrm{~b}$ & $26.5 \mathrm{~b}$ \\
\hline $75 \% \mathrm{FYM}$ & $12399 \mathrm{a}$ & $3428 \mathrm{a}$ & $27.6 \mathrm{~b}$ \\
\hline $50 \% \mathrm{FYM}$ & $11861 \mathrm{ab}$ & $3767 \mathrm{a}$ & $31.8 \mathrm{a}$ \\
\hline $100 \% \mathrm{PM}$ & $9772 \mathrm{~b}$ & $2843 \mathrm{~b}$ & $29.1 \mathrm{ab}$ \\
\hline $75 \% \mathrm{PM}$ & $12082 \mathrm{a}$ & $3540 \mathrm{a}$ & $29.4 \mathrm{ab}$ \\
\hline $50 \% \mathrm{PM}$ & $12027 \mathrm{a}$ & $3742 \mathrm{a}$ & $31.2 \mathrm{a}$ \\
\hline $100 \%$ DAP & $9940 \mathrm{~b}$ & $2688 \mathrm{~b}$ & $27.0 \mathrm{~b}$ \\
\hline LSD $(0.05)$ & 1787 & 401 & 3.2 \\
\hline $\begin{array}{l}\text { Control vs. } \\
\text { rest }\end{array}$ & $* *$ & $* *$ & $* *$ \\
\hline Control & 8269 & 2040 & 24.9 \\
\hline Rest & 11175 & 3238 & 28.9 \\
\hline
\end{tabular}

Means followed by different letters are statistically different from each other at $5 \%$ or $1 \%$ level of probability

NS=non-significant at $5 \%$ level of probability

${ }^{*},{ }^{* *}=$ significant at $5 \%$ and $1 \%$ level of probability respectively

\section{Conclusion}

It is concluded from the results that combined application of organic and inorganic P sources produced 29.3\%, 28.64\% and $24.5 \%$ more yield as compared to the sole application of farmyard manure, DAP, and poultry manure respectively.

Application of $P$ in 50:50 ration of organic and inorganic fertilizer produced $45.8 \%$ more grain yield as compared to control plots.

\section{Recommendation}

Combined use of organic and inorganic fertilizer in 50:50 is recommended for higher maize yield in Peshawar region.

Further studies are required to identify and integration of other organic with inorganic fertilizers on different crops under the different ecological zone of KPK.

\section{References}

1. MNFSR (2014) Agricuture statistics of Pakistan. Ministry of National Food Security and Research, Islamabad, Pakistan.

2. Borch K, Bouma TJ, Lynch JP, Brown KM (1999) Ethylene: A regulator of root architectural responses to soil phosphorus availability. Plant Cell Environ 22: 425-431.

3. Vance CP, Uhde-Stone C, Allan DL (2003) Phosphorus acquisition and use: Critical adaptations by plants for securing a nonrenewable resource. New Phytol 157: 423-447.

4. Oad FC, Buriro UA, Agha SK (2004) Effect of organic inorganic fertilizer application on maize fodder production. Asian J Plant Sci 3: 375-377.

5. Jalil A (2001) Balanced fertilization through phosphate promotion. Project terminal report. National fertilizer development center, Islamabad, Pakistan.
6. Garg S, Bahl GS (2008) Phosphorus availability to maize as influenced by organic manures and fertilizer $P$ associated phosphatase activity in soils. Bioresour Technol 99: 5773-5777.

7. Amanullah, Khalid S (2015) Phenology, growth and biomass yield response of maize to integrated use of animal manures and phosphorus application with and without phosphate solubilizing bacteria. J Microb Biochem Technol 7: 439-444.

8. Vyas P, Gulati A (2009) Organic acid production in vitro and plant growth promotion in maize under controlled environment by phosphate-solubilizing fluorescent Pseudomonas. BMC Microbiol 9: 174.

9. Ibrahim M, Yamin M, Sarwar G, Anayat A, Habib F, et al. (2011) Tillage and farm manure affect root growth and nutrient uptake of wheat and rice under semi-arid conditions of Pakistan. Appl Geochem 26: 194-197.

10. Ahmed S (1994) Agriculture-fertilizer interface in Asian and Pacific Region: Issue of growth, sustainability and vulnerability. Food and Fertilizer Technology Centre, pp: 22.

11. Sarwar MA, Ibrahim M, Tahir M, Ahmad K, Khan Zl, et al. (2010) Appraisal of pressmud and inorganic fertilizers on soil properties, yield and sugarcane quality. Pak J Bot 42: 1361-1367.

12. Ali W, Ali M, Iqbal J, Khalil MK, Ahmad Z (2019) Impact of zinc and organic manure on wheat productivity and soil fertility. Adv Crop Sci Tech 7: 414.

13. Syed MA, Shah SA, Ali S, Iqbal MM (2005) Yield and phosphorus uptake by crops as influenced by chemical fertilizer and integrated use of industrial by products. Songklanakarin J Sci Tech 27: 9-16.

14. Amujoyegbe BJ, Opabode JT, Olayinka A (2007) Effect of organic and inorganic fertilizer on yield and chlorophyll content of maize (Zea mays L.) and sorghum (Sorghum bicolour L.). Moenc Afric J Biotech 6: 1869-1873.

15. Mujeeb F, Rahmatullah, Akhtar J, Ahmad R (2010) Integration of organic and inorganic $P$ sources for improving $P$ use efficiency in different soils. Plant Soil Environ 29: 122-127.

16. Hussain A, Subhanullah, Ali M, Ali W, Tariq M, et al. (2018) Impression of disparate levels of poultry manure and humic acid on the yield and yield traits of maize (Zea mays L.). Eur Exp Biol 8: 23.

17. Jan MT, Shah P, Hollington PA, Khan MJ, Sohail Q (2009) Agriculture research: Design and analysis, a monograph. Agric Univ Pesh Pakistan.

18. Akhtar M, Saeed M, Kaleem SS (1996) Maize productivity as affected by varying seed size and nitrogen levels. Pak J Sci 48: 72-75.

19. Belfield S, Brown C (2008) Field crop manual: Maize. A guide to upland production in Cambodia NSW Dept of Primary Industries, pp: 7-8.

20. Khan F, Khan S, Fahad S, Faisal S, Hussain S, et al. (2014) Effect of different levels of nitrogen and phosphorus on the phenology and yield of maize varieties. Amer J Plant Sci 5: 2582-2590.

21. Amanullah, Khalid S (2015) Phenology, growth and biomass yield response of maize to integrated use of animal manures and phosphorus application with and without phosphate solubilizing bacteria. J Microb Biochem Techno 7: 439-444.

22. Liu Z, Liu X, Craft EJ, Yuan L, Cheng L, et al. (2018) Physiological and genetic analysis for maize root characters and yield in response to low phosphorus stress. Breed Sci 68: 368-277. 
23. Ali M, A Ali, M Tahir, M Yaseen (2012) Growth and yield response of hybrid maize through integrated phosphorus management. Pak J Life Soc Sci 10: 59-66.

24. Ali W, Ali M, Ahmad Z, Igbal J, Anwar S, et al. (2018) Influence of sowing dates on varying maize (Zea mays I.) varieties grown under agro-climatic condition of Peshawar, Pakistan. Eur Exp Biol 8: 36.

25. Udom GN, Bello HM (2009) Effect of poultry litter on the yield of two maize varieties in the northern gulnea savanna. J Trop Agric Food Environ Exten 8: 51-54.

26. Luo $B, M a ~ P, ~ N i e ~ Z$, Zhang $X$, He $X$, et al. 2018. Combining metabolite profiling with genome-wide association study to reveal response mechanisms of Zea mays seedlings under lowphosphorus condition. Plant J
27. Masood T, Gul R, Munsif F, Jalal F, Hussain Z, et al. (2011) Effect of different phosphorus levels on the yield and yield components of maize. Sarhad J Agric 27: 167-170.

28. Imran, Khan AA (2015) Grain yield and phenology of maize cultivars influenced by various phosphorus sources. Food Sci Qual Manag 37: 74-78.

29. Mukhtiar A, Waqar A, Khalil MK, Tariq M, Muhammad S, et al. (2018) Evaluating the Potential Organic Manure for Improving Wheat Yield and Quality under Agro-Climatic Conditions of Pakistan. Adv Crop Sci Tech 6: 349. 